\title{
Impacts of Water Hyacinth (Eichhornia crassipes) on the Fishing Communities of Lake Naivasha, Kenya
}

\section{Edna Waithaka*}

Kenya Marine and Fisheries Research Institute, Kenya

\begin{abstract}
A survey was conducted on the three gazetted landing beaches along the shores of Lake Naivasha by Kenya Marine and Fisheries Research Institute staff. The objectives of the study were to assess the existing knowledge and perception of the fisher community on the causes and impacts of the water hyacinth in Lake Naivasha and to identify and recommend possible solutions to control the hyacinth infestation.

The study found that the fisher communities are very knowledgeable of the effect of the water hyacinth. Observing fish kills caused by oxygen depletion as a major impact of water hyacinth infestation which also impacted negatively on their socio- economic status.

With fishing observed as their main occupation they recommended that the resource managers strive to stem Proliferation of the water hyacinth in order to create a viable condition for fishery production. Their hope of sustaining themselves economically would be made possible through participatory management approach in ensuring that the health of the lake's ecosystem is kept in check.
\end{abstract}

Keywords: water hyacinth, infestation, health, participatory management, ecosystem

\section{Introduction}

Lake Naivasha is a Ramsar wetland of International importance situated in the Great Riftvalley of Kenya. It is an endorheic lake with an area of about $140 \mathrm{~km}^{2}$ and mean depth varying between $4 \mathrm{~m}$ and $6 \mathrm{~m}$. Its freshness is maintained due to water and salt loss by underground seepage [1].

The wetland supports large and important economic activities including irrigated horticulture, fishery, tourism and geothermal power generation.Water hyacinth (Eichhornia crassipes) was first recorded in Lake Naivasha in 1988, where it occurred in protected bays and estuaries, hindering navigation. The water conditions were however not conducive for it to spread throughout the lake at that time. In the recent past the environmental conditions at Lake Naivasha have changed markedly due to spatial and temporal dynamics of the water quality parameters and have shifted from clear water macrophyte dominated conditions to turbid conditions $[2,3]$, which are water hyacinth infested with periods of water hyacinth regeneration. Previously the dominant floating macrophytes were Papyrus (Cyperus papyrus), Nile cabbage (Pistia stratiotes), Wolffia arrhiza and water lily (Nymphaa caerulea). The water hyacinth and other submerged plants vary considerably and cover about two thirds of the lake, exerting considerable influence on the ecology and water chemistry of the lake.

Described are the results of a survey of the fisher community of Lake Naivasha. to determine the level of understanding of the causes and impact of water hyacinth on Lake Naivasha; and to find possible solutions to control the infestation of the water hyacinth in the lake. The objectives of the study were first to assess the existing knowledge and perception of the fisher community of the causes and impacts of the water hyacinth in Lake Naivasha and second to identify and recommend possible solutions to control the hyacinth infestation.

\section{Methodology}

The survey was conducted between August and September 2011.
Kenya Marine and Fisheries Research Institute staff administered open ended questionnaires to fishers and fish traders at the three gazetted landing beaches along the shores of Lake Naivasha; the central landing beach, Tarambete landing beach and Kamere landing beach (Figure 1). A total of 12 questions were asked and the data was compiled and analysed in Microsoft excel.

\section{Results}

A total of 102 fishers and fish traders were interviewed out of the existing 150 fishers and fish traders in Lake Naivasha; 25 in Kamere, 19 in Tarambete, and 58 at the central landing beach

Fishing on Lake Naivasha is mainly male youth dominated with a gender distribution of male respondents at $76 \%$ followed by the females respondents at $24 \%$. However participation of women owning boats has become increasingly prominent.

The age distribution of the fishers ranged from 19 to 65 years with the age class of 20 to 30 years having the highest numbers of respondents and the class of over 60 having the least number of respondents at all landing beaches.This implies that the fishery of Lake Naivasha is highly dynamic and has created fertile grounds for new entrants most especially school drop outs, who cite lack of school fees and increasing poverty levels as a reason for them to join the fishery sector (Figure 2).

The study found that a large number of the respondents have been in the industry for less than ten years and have undergone some level of formal schooling. Their level of education ranged between primary

*Corresponding author: Edna Waithaka, Kenya Marine and Fisheries Research Institute, P.O Box 837, Naivasha, Kenya, E-mail: ewaithaka@yahoo.com

Received May 27, 2013; Accepted August 13, 2013; Published August 19, 2013

Citation: Waithaka E. (2013) Impacts of Water Hyacinth (Eichhornia crassipes) on the Fishing Communities of Lake Naivasha, Kenya. J Biodivers Endanger Species

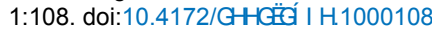

Copyright: (c) 2013 Waithaka E, et al. This is an open-access article distributed under the terms of the Creative Commons Attribution License, which permits unrestricted use, distribution, and reproduction in any medium, provided the original author and source are credited. 
to tertiary level with the primary level having the highest number of respondents (Figure 3).

Most of the interviewees (especially the fishers) admitted knowledge of the water hyacinth in the lake which is also called "Alonga" in the local dialect. While most of the fish traders interviewed were not sure which weed among the existing weeds is water hyacinth, they lamented the effect it has had on the fish catches since some of them lack enough fish to sell.

The fishers cited various reasons as being the cause or trigger of the water hyacinth proliferation in the lake. The most cited reason included heavy rainfall, nutrient enrichment from the lake's catchment, and lack of proper management to ensure proper resource use by all. A summary of the reasons given for the proliferation of the weed in the lake are as shown in Figure 4.

The fishers described the effects of the water hyacinth on the fishing

\section{Lake Naivasha Basin}
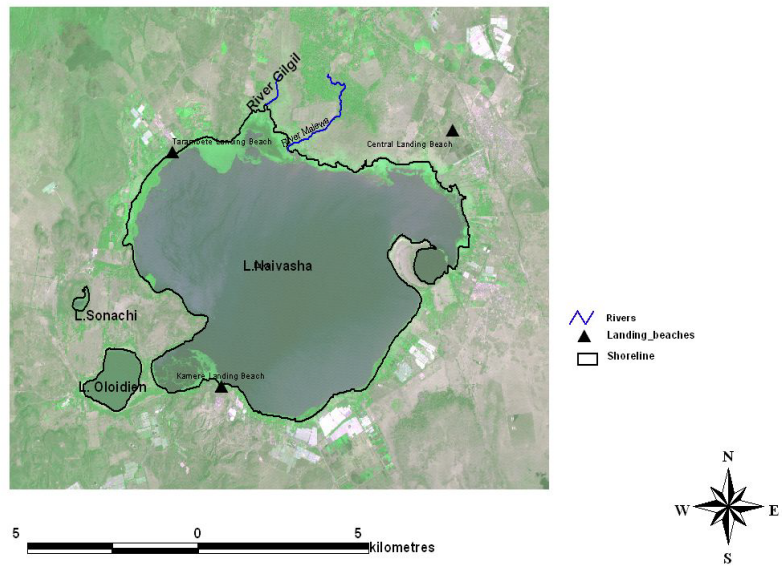

Figure 1: Map of Lake Naivasha landing beaches

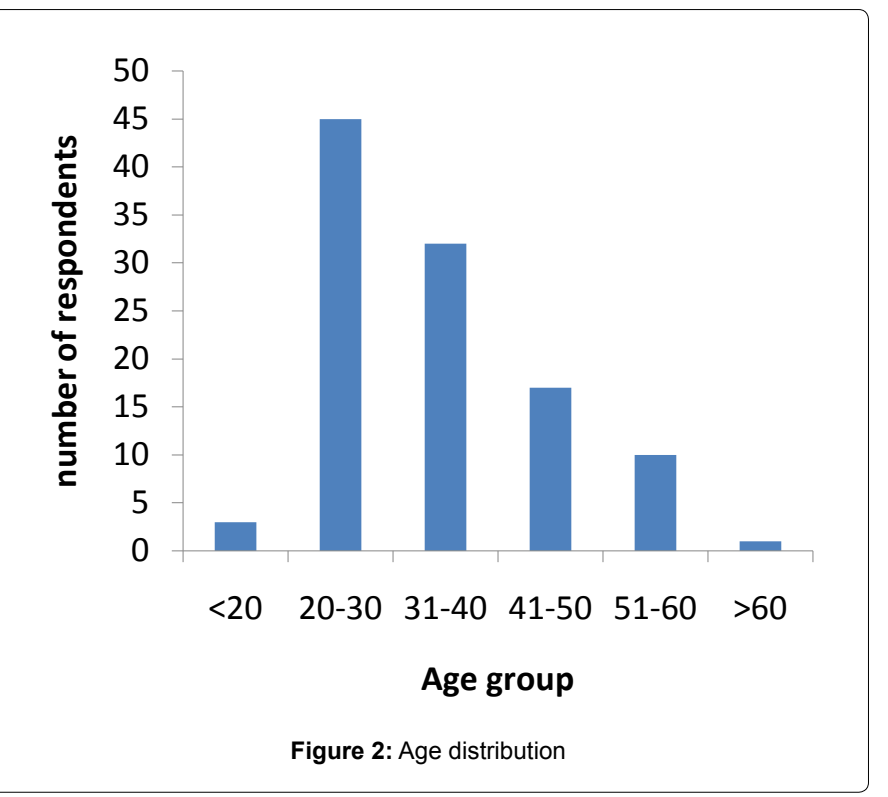

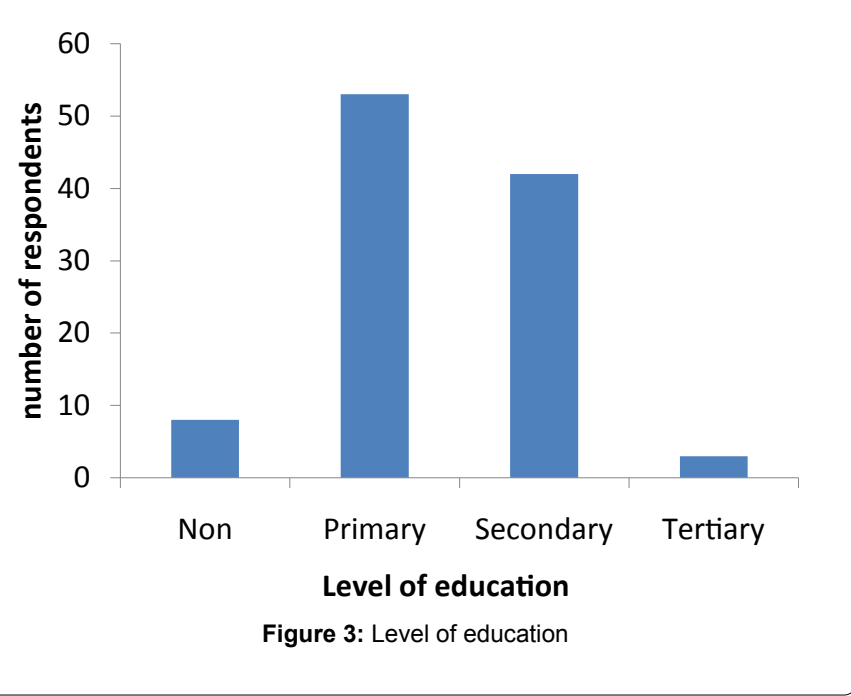

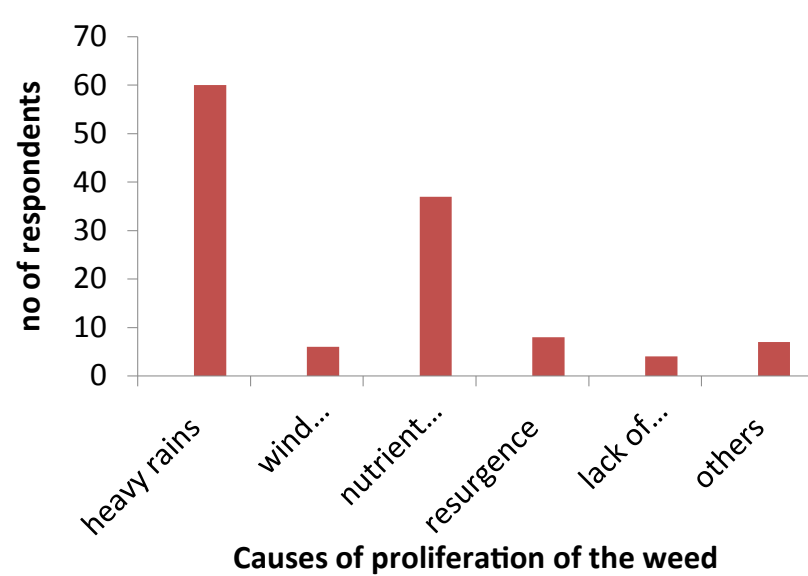

Figure 4: Reasons cited for water hyacinth proliferation

communities as destructive, as it destroys the fishing gears, reduces fish catch, blockage of landing sites, and hence reduced income (Figure 5).

The areas cited as mostly affected by water hyacinth during and after the rainy season included the nutrient rich bays such as Oserian Bay, Yatch, Kasarani, Kamere and Malewa river mouths with the southern part of the lake being the most affected (Figure 6).

Various responses were extended on the question of whether the water hyacinth affected other biota in the lake. Some of the responses by the interviewees included fish kills due to reduced oxygen levels in the lake and displacement of fish and other animals from inshore nursery and feeding habitats, especially for the water birds and hippopotamus.

Most fishers were of the opinion that the most suitable and preferred method of eradicating the weed from the lake was by manual removal due to availability of labour, The second most preferred method of removal of the weed was use of machines, which some respondents felt would be effective. A few respondents were of the opinion that chemical control was a good way to eradicate the weed (Figure 7). What the 
fishers want are high fish catches and they have a serious need for the lake's health to be restored.

The study also sought to establish whether the fisher communities saw any economic value in the water hyacinth. Most respondents were of the opinion that the water hyacinth can be used to make fertilizers, biogas, animal feed and furniture respectively. Other respondents saw the hyacinth as a socio-economic reward providing job opportunities for manual weed biomass removal (Figure 8)

\section{Discussions}

The study found that the fisher communities around Lake Naivasha were extremely knowledgeable of their environment and issues affecting the lake ecosystem. The future health of the lake depends largely on the positive actions taken by both the resource users and managers in addressing the challenges facing the resource. For instance, the inevitable declining trend in rainfall patterns is threatening the existence of the Lake Naivasha ecosystem. Protection of the rain catchment area is a strong policy statement which is well articulated but has benefited least in terms of implementation. Therefore an integrated catchment and basin management approach should be adopted in order to achieve sound management of the lake's biota.

In Lake Victoria the hyacinth provided both positive and negative environmental impacts. The positive environmental benefits included enhanced availability of refugia and feeding centre's for fish and various

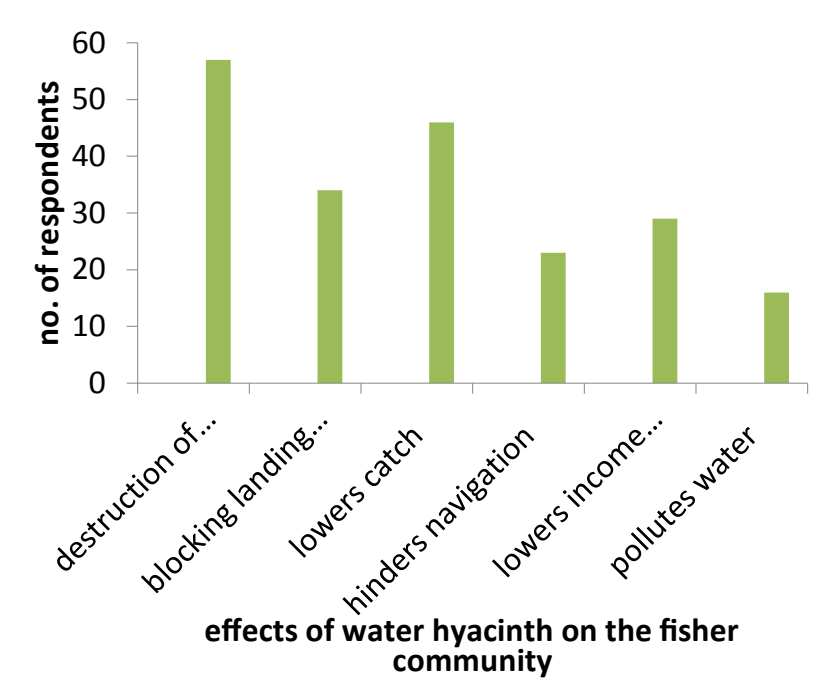

Figure 5: Effects of the water hyacinth on the fishing communities

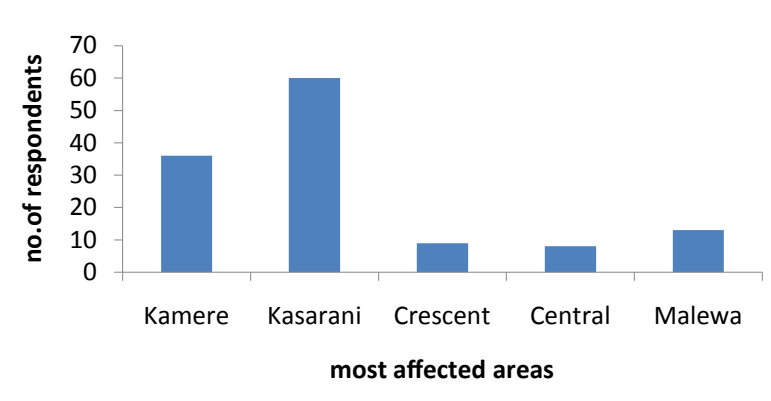

Figure 6: Most affected areas

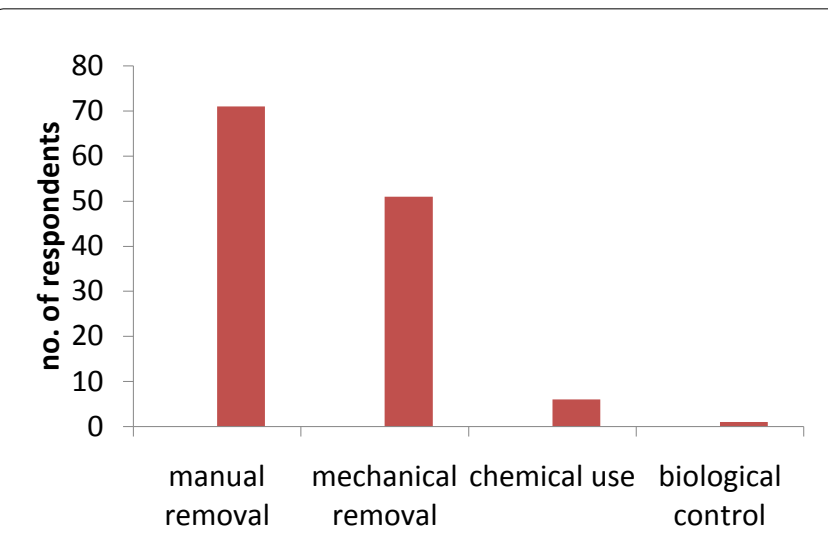

methods of eradicating the water hyacinth

Figure 7: Methods of eradicating the water hyacinth

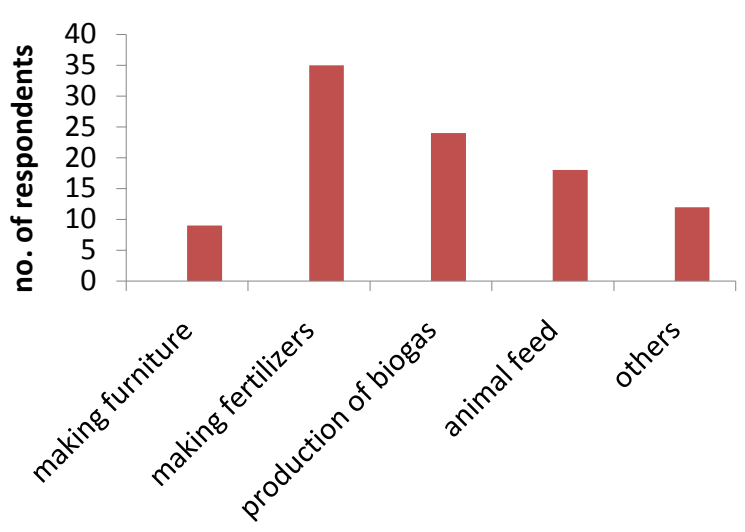

other economic uses of the water hyacinth

Figure 8: Economic uses of the water hyacinth

other aquatic fauna at narrow stationery fringes of the weed whose roots were regularly flushed with well oxygenated waters. Such water hyacinth fringes were rich in a variety of algae, and various invertebrates [4].

According to Willoughby et al [5], negative environmental impacts of the water hyacinth in Lake Victoria included displacement of biodiversity through degradation of water quality and smothering of habitats by extensive, permanent water hyacinth cover

The water under the interior of extensive stationary mats of water hyacinth was virtually devoid of oxygen, particularly late in the night and early in the morning. In Lake Naivasha massive fish kills were reported in February 2010 after the resurgence of the weed and this was attributed to reduced oxygen levels which were below $2 \mathrm{mg}^{-1} \mathrm{l}^{-1}$. The thick surface cover of the weed restricted diffusion of atmospheric oxygen into the water while the decay processes of dead weed debris depleted most of the oxygen accumulated. Restricted diffusion of oxygen may have reduced or eliminated growth of algae and aquatic macrophytes on Lake Naivasha and extensive stationery mats have displaced fish and other animals from inshore nursery and feeding habitats $[5,6]$. Refugia for the biodiversity, originally provided under the native macrophytes, were lost. 
Citation: Waithaka E. (2013) Impacts of Water Hyacinth (Eichhornia crassipes) on the Fishing Communities of Lake Naivasha, Kenya. J Biodivers

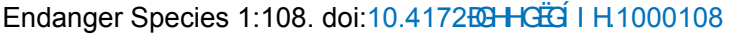

\section{Conclusions}

The effect of the water hyacinth infestation has been observed to have a negative impact on the economic status of the fisher community in regard to fish kills caused by oxygen depletion. Not much has been done in regards to utilization of the water hyacinth with the hope of reducing its biomass in Lake Naivasha, although the community expects creation of jobs on manual harvesting of the weed.

The resource managers should in future consider making use of the water hyacinth as witnessed around Lake Victoria. They should also strive to stem proliferation of the water hyacinth in order to create a viable condition for fishery production.

The fishers and communities around Lake Naivasha depend largely on the Lake as a source of their livelihood. Their hope of sustaining themselves economically should be made possible through participatory management approach to ensure the health of the lake's ecosystem.

\section{References}

1. Gaudet JJ, Melack JM (1981) Major ion chemistry in a tropical African lake basin. Fresh water bio 11: 309-333.

2. Harper D, Mavuti K (2004) Lake Naivasha, Kenya: ecohydrology to guide the management of a tropical protected area. Ecohydrology and Hydrobiology 4 : 287-305.

3. Britton JR, Boar RR, Grey J, Foster J, Lugonzo J et al (2007) From introduction to fishery dominance: the initial impacts of invasive carp cyprinus carpio in Lake Naivasha, Kenya 1999 to 2006. Journal of Fish biology 71: 239-257.

4. Wanda FM, Twongo T, Denny P (2001) The impacts of water hyacinth eichhornia crassipes (Mart) Solms on the abundance and diversity of aquatic macro invertebrates along the shores of northern Lake Victoria, Uganda. Hydrobiologia 452: 79-88.

5. Willoughby NG, Watson IG, Laver S, Grant IF (1993) The effects of water hyacinth on the biodiversity and abundance of fish and invertebrates in Lake Victoria, Uganda. Final technical Report. Natural Resources Institute, Overseas Development Association. United Kingdom.

6. Willoughby IG, Watson IG, Twongo T (1996) Preliminary studies on the effects of water hyacinth on the diversity, abundance and the ecology of fish fauna in Lake Victoria, Uganda. 